\title{
Lipoprotein (a) and Ultrasensitive C-Reactive Protein in Overweight Adolescents
}

\author{
Débora Larissa Rufino Alves ${ }^{1}$, Camilla Ribeiro Lima de Farias², \\ Ivelise F. A. F. da Costa ${ }^{2}$, Mônica Oliveira da Silva Simões ${ }^{3}$, \\ Carla Campos Muniz Medeiros ${ }^{4}$, Danielle Franklin de Carvalho ${ }^{4}$ \\ ${ }^{1}$ Department of Nursing, State University of Paraiba, Campina Grande, Brazil \\ ${ }^{2}$ Graduate Program in Public Health, Centre for Epidemiological Research, State University of Paraiba, Campina \\ Grande, Brazil \\ ${ }^{3}$ Department of Pharmacy, Graduate Program in Public Health, Centre for Epidemiological Research, State \\ University of Paraiba, Campina Grande, Brazil \\ ${ }^{4}$ Department of Nursing, Graduate Program in Public Health, Centre for Epidemiological Research, State \\ University of Paraiba, Campina Grande, Brazil \\ Email: rufino.debora@hotmail.com, camilla ribeiro@hotmail.com, ivelisefurtado@gmail.com, \\ moscg@uol.com.br, carlamunizmedeiros@hotmail.com, daniellefranklin6@gmail.com
}

Received 23 July 2014; revised 10 September 2014; accepted 24 October 2014

Copyright (C) 2014 by authors and Scientific Research Publishing Inc.

This work is licensed under the Creative Commons Attribution International License (CC BY). http://creativecommons.org/licenses/by/4.0/

c) (i) Open Access

\section{Abstract}

Introduction: The more intense and early development of obesity, the greater the risk of persistence and severity of co-morbidities, such as cardiovascular disease. There is evidence that high serum concentrations of lipoprotein (a) [Lp (a)] and C-reactive protein (CRP) are associated with increased risk of cardiovascular diseases. Objectives: To verify the change in the levels of Lp (a) and ultrasensitive CRP and its relationship with the nutritional status of adolescents. Methods: Cross-sectional study conducted with overweight children and adolescents between August 2012 and July 2013 attended at the Center for Childhood Obesity. The measurement of inflammatory markers was performed in the Clinical Laboratory of the State University of Paraiba. Comparison of sociodemographic variables by sex was tested by chi-square; the association of the risk markers according to age was evaluated by Student's $t$ test, and the body mass index by analysis of Pearson correlation. The normality distribution was tested by the Kolmogorov-Smirnov test. Confidence interval of $95 \%$ was adopted in all analyses. The study was approved by the Ethics Research Committee of UEPB (CAAE 0256.0.133.000-11). Results: Of the 133 children and adolescents evaluated, $\mathbf{6 0 . 9 \%}$ were female and $\mathbf{7 2 . 2 \%}$ were adolescents. Body Mass Index, lipo (a) and u-CRP showed statistically significant association with age $(\mathrm{p}<0.01)$. There was a positive ascending correlation $(r$ 
$=0.273, \mathrm{p}<0.01$ ) of $\mathrm{u}$-CRP with BMI, which was not verified for lipoprotein (a). Conclusion: As a cardiovascular risk marker already established in literature, the association of u-CRP with the nutritional status of adolescents, proportionally, shows the need for losing weight in this population, especially at early age. A deeper and long-term investigation should be carried out for more effective and consistent contribution to public health.

\section{Keywords}

\section{Children, Adolescents, Obesity, Lipoprotein, C-Reactive Protein}

\section{Introduction}

Obesity is a multifactorial condition involving genetic and environmental components [1] that represent a public health problem since it affects different populations, regardless of stage of life and socioeconomic status [2]. In Brazil, the Brazilian Institute of Geography and Statistics (IBGE) indicates that among children aged 5 - 9 years, one in three is overweight, $14.3 \%$ of them are obese [3]. In the adolescent population, $19.4 \%$ of girls and $21.7 \%$ of boys present similar diagnosis [4].

This physical condition is considered the most relevant nutritional problem among children [1], since individuals with a prevalence of fat in body composition are more likely to develop chronic degenerative diseases [5]. The more intense and early development of obesity, the greater the risk of persistence and severity of co-morbidities, such as cardiovascular disease, hypertension, diabetes and some types of cancers [2]. These diseases were more frequent among adults, but are now occurring increasingly early, whose identification is essential in the early stages of life [5].

There is a consensus that cardiovascular disease (CVD) is a multifactorial etiology including, in addition to lifestyle, atherosclerotic, prothrombotic and inflammatory components. Thus, in addition to the evaluation of conventional risk factors, new markers have been explored in prospective observational studies in order to improve the capacity of predicting the risk of cardiovascular events [6].

There is evidence that elevated serum lipoprotein (a) [Lp (a)] and C-reactive protein (CRP) concentrations are associated with increased risk of cardiovascular diseases, which classify them as potential risk markers [7].

Lp (a) lipoprotein is a plasma lipoprotein, similar to the LDL particle (low density lipoprotein), as a apolipoprotein B molecule (Apo B) and an additional protein, apolipoprotein A (Apo A). Recent studies have reported that Lp (a) is a stable risk marker of major forms of vascular diseases, with atherogenic and thrombotic properties [8].

Ultrasensitive CRP (u-CRP) is produced in the liver in response to stimulation of inflammatory cytokines. An inflammatory marker has been widely used for detection of CVD. Prospective studies have demonstrated that elevated u-CRP levels are associated with increased risk of several manifestations of CVD, including myocardial infarction, stroke, sudden death and systemic blood hypertension (SBH) [9].

The diagnosis and interventions during childhood and adolescence have been recommended to prevent the development of chronic diseases in adulthood [10], since studies show that there is a risk at least twice greater developing obesity in adulthood for obese compared to non-obese children [11]. Thus, this study aims to assess the prevalence of changes in risk markers, lipoprotein A and ultrasensitive C-reactive protein and its relation to the nutritional status of children and adolescents.

\section{Methods}

\subsection{Study Location and Design}

Cross-sectional study conducted at the Centre for Childhood Obesity (CCO) and Clinical Laboratory (LAC) of the State University of Paraiba, Campina Grande, PB, Brazil, between August 2012 and July 2013.

\subsection{Population and Sample}

The sample was composed of children and adolescents aged 2 - 19 years with diagnosis of overweight or obesity attended at CCO. Those using medications or conditions that could compromise the glucose or lipid metabolism 
such as kidney, liver diseases; pregnancy or the presence of inflammatory diseases were excluded.

\subsection{Study Variables}

The recruited patients completed a checklist to verify the inclusion/exclusion criteria of the study and parents/guardians signed then informed consent form for participation. The following variables were considered: age (classified into two age groups: 2 - 9 years and 10 to 19 years); sex; color (classified as white or nonwhite); income (in accordance with the minimum wage at the time of the study) and per capita income, considering the family members residing with the patient; type of school (public or private). In addition to the socioeconomic and demographic information through questionnaire, anthropometry was performed (weight and height) for classification of nutritional status, and blood collection for biochemical testing of Lp (a) and u-CRP.

Welmy ${ }^{\circledR}$ digital scale with sensitivity of $100 \mathrm{~g}$ and stadiometer with scale of $1 \mathrm{~mm}$ were used. In addition to the evaluation as continuous variable, body mass index (BMI) was used to determine nutritional status, according to the $\mathrm{z}$ score and to age: overweight $(+1 \geq \mathrm{z}$ score $<+2)$, obesity $(+2 \geq \mathrm{z}$ score $<+3)$ and severe obesity ( $\mathrm{z}$ score $\geq+3)$. For over 18 years of age, the cutoff points for BMI $\left(\right.$ in $\left.\mathrm{kg} / \mathrm{m}^{2}\right)$ were: overweight $(25.0 \leq \mathrm{BMI}<30.0)$ and obesity $\left(\geq 30.0 \mathrm{~kg} / \mathrm{m}^{2}\right)$ [12]. For purposes of analysis, obesity and severe obesity variables were grouped into only one category.

Lipoprotein (a) was measured by immunoturbidimetry technique using in vitro lipoprotein (a) turbidimetric diagnosis. For interpretation of Lp (a), values above $30 \mathrm{mg} / \mathrm{dL}$ were considered elevated. Serum u-CRP was determined y chemiluminescence. The levels of this protein have been classified into low-risk for cardiovascular values $<1 \mathrm{mg} / \mathrm{L}$, moderate risk values between 1 and $3 \mathrm{mg} / \mathrm{L}$ and increased risk levels $>3 \mathrm{mg} / \mathrm{L}$. Samples $\geq 10$ $\mathrm{mg} / \mathrm{L}$ were excluded for suggesting acute infectious or inflammatory process.

\subsection{Data Collection Procedures}

Data collection was performed after the clarification of all procedures adopted, including the need to fast for 12 hours prior to the day of blood collection. Parental consent was required by signing the Free and Informed Consent Form (ICF). Blood for the determination of lipids was collected in schools by specialized technicians at previously scheduled day, always in the morning. Samples were processed and analyzed by outsourced laboratory (enzymatic colorimetric method), hired for this purpose, with Lab-SPC/ML quality control seal.

\subsection{Data Processing and Statistical Analysis}

For statistical analysis, data were described as mean, standard deviation and frequencies, analyzed using the SPSS 22.0 program. The distribution of sociodemographic variables by sex was tested by chi-square; risk markers with age by Student's t test and correlation with BMI by Pearson correlation analysis. The normality distribution was tested by the Kolmogorov-Smirnov test. Confidence interval of 95\% was adopted in all analyses.

\subsection{Ethical Aspects}

Ethical standards in research with human beings according to the letter of Helsinki have been applied. The project was approved by the Ethics Research Committee of UEPB (CAAE: 0256.0.133.000-11).

\section{Results}

Of the total of 133 children and adolescents evaluated, 60.9\% $(n=81)$ were female, $72.2 \%(n=96)$ adolescents, $63.2 \%(n=84)$ with income below or equal to two minimum wages and per capita income of $R \$ 366.93$. Sociodemographic variables are described in Table 1.

The prevalence of obesity was $80.5 \%(n=107)$. Changing lipo (a) happened in $42.1 \%(n=56)$ of cases and u-CRP alteration was 39.8\% $(n=53)$. Tests with clinical and biochemical variables (BMI, lipo (a) and u-CRP) stratified according to gender were performed. However, no statistically significant differences ( $p>0.05)$ were found. However, when assessing these variables by age group, difference for all ages was found, as expected. Age, therefore, appears as an independent risk factor, although at early ages (Table 2).

Figure 1 and Figure 2 show the correlation of the two markers evaluated with respect to body mass index. Contrary to expectations, although with weak correlation with BMI, lipoprotein (a) showed reverse correlation ( $\mathrm{r}$ $=-0.195, \mathrm{p}=0.03)$. This may have occurred due to the amplitude of results $(2-113 \mathrm{mg} / \mathrm{l})$ probably due to the wide age range, since children and adolescents were evaluated. With respect to u-CRP, an ascending positive 
Table 1. Sample distribution in terms of socioeconomic and demographic characteristics, according to sex. Campina Grande, PB, 2012-2013.

\begin{tabular}{|c|c|c|c|c|c|}
\hline \multirow{2}{*}{ CHARACTERISTICS } & \multicolumn{2}{|c|}{ MALE } & \multicolumn{2}{|c|}{ FEMALE } & \multirow{2}{*}{ p-value (CI 95\%) } \\
\hline & $\mathbf{n}$ & $\%$ & $\mathbf{n}$ & $\%$ & \\
\hline \multicolumn{6}{|l|}{ Age group } \\
\hline Children & 23 & 34.6 & 22 & 23.5 & \multirow{2}{*}{$0.22(0.26-1.24)$} \\
\hline Adolescent & 29 & 65.4 & 58 & 76.5 & \\
\hline \multicolumn{6}{|l|}{ Color } \\
\hline White & 18 & 34.6 & 28 & 34.6 & \multirow{2}{*}{$0.85(0.48-2.08)$} \\
\hline Non white & 34 & 65.4 & 53 & 65.4 & \\
\hline \multicolumn{6}{|l|}{ School } \\
\hline Public & 33 & 63.5 & 43 & 53.1 & \multirow{2}{*}{$0.31(0.75-3.13)$} \\
\hline Private & 19 & 36.5 & 38 & 46.9 & \\
\hline
\end{tabular}

Children: 2 - 9 years; Adolescents: 10 - 19 years.

Table 2. Sample distribution according for cardiovascular risk markers according to age. Campina Grande, PB, 2012-2013.

\begin{tabular}{cccccc}
\hline \multirow{2}{*}{ MARKERS } & \multicolumn{2}{c}{ CHILD } & \multicolumn{2}{c}{ ADOLESCENT } & \multirow{2}{*}{ p-value (CI 95\%) } \\
\cline { 2 - 4 } & Mean & SD & Mean & SD & \\
BMI $\left(\mathrm{kg} / \mathrm{m}^{2}\right)$ & 26.3 & 4.7 & 30.5 & 6.2 & $<0.01(28.3-30.4)$ \\
Lipo (a) (mg/dL) & 38.6 & 28.8 & 29.8 & 28.9 & $<0.01(27.2-37.4)$ \\
u-CRP (mgLl) & 3.4 & 5.4 & 3.6 & 3.9 & $<0.01(2.9-4.4)$ \\
\hline
\end{tabular}

BMI: Body mass index; Lipo (a): Lipoprotein (a); u-CRP: Ultrasensitive C-reactive protein; SD: Standard deviation; CI: Confidence interval.

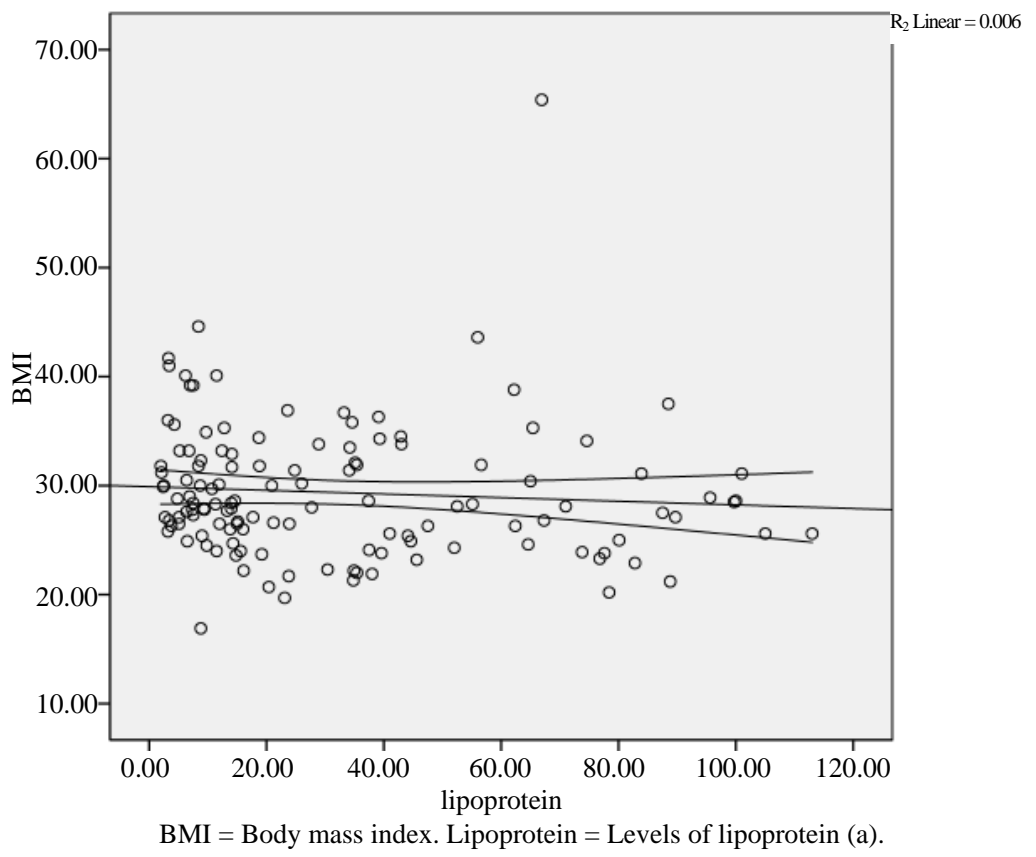

Figure 1. Correlation between lipoprotein (a) and body mass index in children and adolescents. Campina Grande, PB, 2012-2013. 


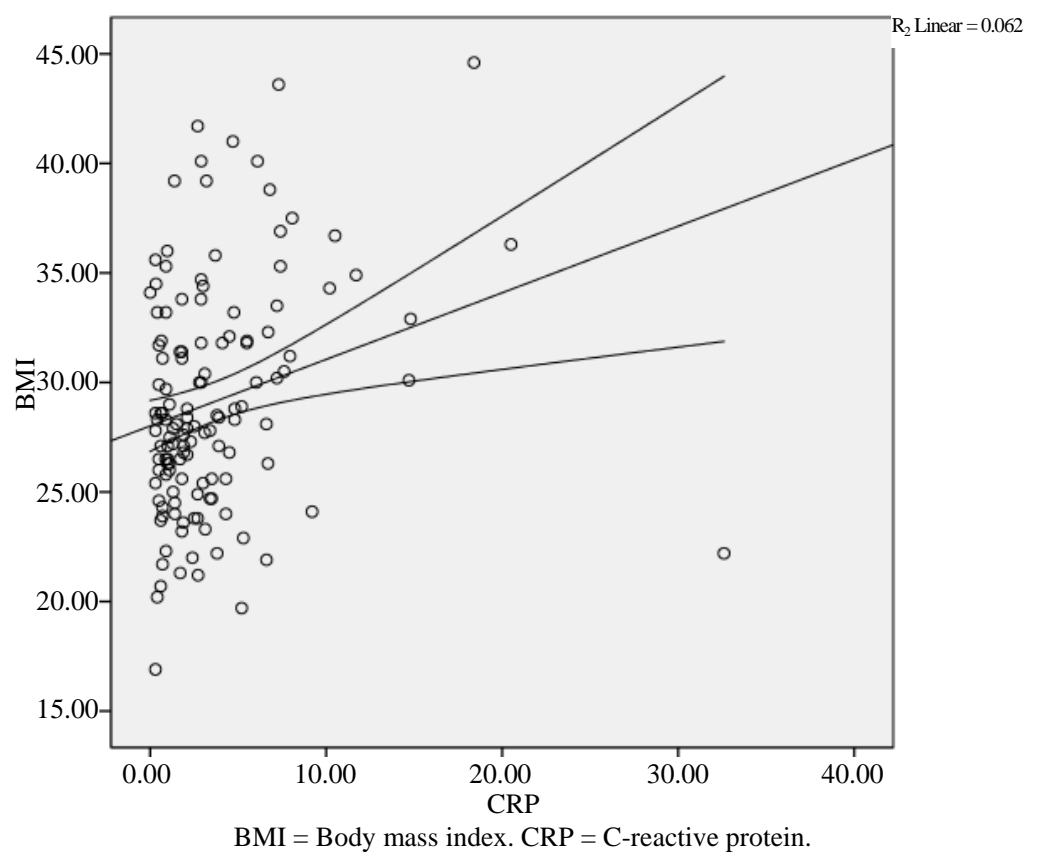

Figure 2. Correlation between ultrasensitive C-reactive protein and body mass index in children and adolescents. Campina Grande, PB, 2012-2013.

correlation with BMI was found $(r=0.273, \mathrm{p}<0.01)$.

\section{Discussion}

The prevalence of obesity during childhood and adolescence has increased rapidly in both developed countries and developing countries, reaching proportions considered epidemics [13]. This condition is a major risk factor for many health conditions, especially cardiovascular diseases, certain types of cancers and respiratory diseases, adversely affecting the quality of life of people. In addition, obese children have a much higher risk of remaining obese at adult age [14]. This has led to an increasing interest in research of risk markers that may predict possible future cardiac events, such as lipoprotein (a) and ultrasensitive C-reactive protein.

Similar to the findings of Nascimento et al. (2012) [15], who in a cross-sectional study found a $54.7 \%$ female with mean age 11 years; of the 133 patients evaluated in this study, there were more girls (60.9\%) and adolescent age group (72.2\%).

As for skin color variable, 66.2\% were nonwhite, corresponding to the findings of Wood et al. (2009) [16], whose prevalence ranged from $63.3 \%$ in the obese group and $54.8 \%$ in the overweight group. Although in this study this variable was not analyzed according to the nutritional status, it appears that the prevalence remains high.

With regard to family income, a quantitative of two or more minimum wages for only $33.8 \%$ of family members was shown. These values are lower than those obtained by Ramos et al. (2011) [17] in a study conducted in the city of Campina Grande, in 2009, which showed $42.2 \%$ for this variable, a difference of $9.2 \%$ in the economic condition.

Regarding the type of school, 66\% reported public schools, corroborating the findings of Rossetti et al. (2009) [18], who identified an even higher percentage in their research, $80 \%$. The fact that this study included children and adolescents attended in a public specialized service with predominance of low family income can explain this high percentage.

The evaluation of socioeconomic and demographic variables stratified by sex showed no statistically significant difference. Similar results were observed by Costa et al. (2012) [19], who found no variation by gender.

BMI was associated with age, the same was not observed for lipoprotein (a) and u-CRP. Similarly, in the study by Khan et al. (2010) [20], average lipoprotein (a) was greater in adolescents, which may be due to the fact that body mass index was also higher in this population. 
u-CRP showed similar averages for both children and adolescents, corroborating the findings of Kitsios et al. (2009) [21]. In this case, positive correlation between u-CRP levels in overweight and obese children and adolescents was also observed. The difference of the correlation observed for markers investigated in his study differ from studies conducted by Cordero et al. (2011) [22] and Nascimento et al. (2012) [15], which showed a significant correlation for both variables. As for u-CRP, the ascending correlation with BMI was similar to results shown by Nascimento et al. (2012) [15].

Recent studies with similar population found associations between CRP and BMI. Eight European countries, in 2013, showed correlation between the above markers. Even stratified by sex, which differs from the present study, the values for $p$ were statistically significant (male: $p=0.000062$; female: $p=0.001$ ) [23]. In another study conducted in the same year, in the city of Rio de Janeiro (Brazil), was evidenced similar association between the same markers, with values of $r=0.51$ and $p<0.0001$ [24].

With respect to the Lp (a), Cohen and Damasceno (2013), in a study conducted in São Paulo with 137 schoolchildren, to analyze the molecules of apolipoprotein A and B, plasma markers that comprise the lipo (a), depending on the classification of BMI, was found that the obese group $(n=66)$ showed higher values than normal weight $(\mathrm{n}=71)$ for Apo B ( $<<0.01)$. The opposite profile was observed for the variable Apo AI ( $<$ 0.01). However, when the sample was stratified by gender, it was found that in eutrophic group, the variable Apo AI ( $\mathrm{p}=0.027)$ and Apo B ratio/Apo AI (0.027) were significantly higher in males [25].

\section{Conclusions}

Lipo (a) and u-CRP are risk markers for CVD and may be altered in early stages of life, as in the pediatric age group. These markers seem to have relationship with overweight, having high prevalence of changes in overweight population. Although lipo (a) has not shown growing relationship with BMI, this result has been observed for CRP. This reinforces, in both cases, the need for early detection and intervention.

Given the above, a deeper and long-term investigation for the complementation of these results is needed for a more effective and consistent contribution to public health. Health professionals should be prepared to prevent and identify possible early risk groups in order to treat them with greater attention. The prevention and treatment of obesity from childhood can aid in reducing the risk of developing chronic diseases in adulthood, thus improving the quality of life of this population.

\section{Acknowledgments}

We would like to thank CNPq, researchers at the Centre for Epidemiological Studies and Research at the State University of Paraiba and Center for Childhood Obesity.

\section{References}

[1] Kluczynik, V.C.E., et al. (2013) Assistência de enfermagem na puericultura: Acantose nigricans como marcador de risco metabólico. Revista Latino-Americana de Enfermagem, 21, 1220-1227. http://dx.doi.org/10.1590/0104-1169.2870.2357

[2] Leal, V.S., et al. (2012) Excesso de peso em crianças e adolescentes no Estado de Pernambuco, Brasil: Prevalência e determinantes. Cadernos de Saude Publica, 28, 1175-1182. http://dx.doi.org/10.1590/S0102-311X2012000600016

[3] Azambuja, A.P.O., et al. (2013) Prevalência de sobrepeso/obesidade e nível econômico de escolares. Revista Paulista de Pediatria, 31, 166-171. http://dx.doi.org/10.1590/S0103-05822013000200006

[4] Salvatti, A.G., et al. (2011) Padrões alimentares de adolescentes na cidade de São Paulo. Revista de Nutrição, 24, 703-713. http://dx.doi.org/10.1590/S1415-52732011000500004

[5] Rodrigues, J.C. (2013) Obesidade Infantil: Uma verdadeira epidemia [Trabalho de Conclusão de Curso]. Faculdade de Ciências da Educação e Saúde-FACES, Curso de Licenciatura em Educação Física, Brasília, DF.

[6] Silva, J.R.S. (2012) Avaliação da Proteína C-Reativa como Preditor para Doenças Cardiovasculares [Trabalho de Conclusão de Curso]. Universidade Estadual da Paraíba-UEPB, Curso de Farmácia, Campina Grande.

[7] Palmeira, A.C. (2013) Lipoproteína (A) e fatores de risco cardiovascular em crianças e adolescentes. 2013.83 f. Dissertação [Mestrado em saúde Pública]—Pró-Reitoria de Pós-Graduação e Pesquisa, Universidade Estadual da Paraíba, Campina Grande.

[8] Silva, L.R., et al. (2012) Aterosclerose subclínica e marcadores inflamatórios em crianças e adolescentes obesos e não 
obesos. Revista Brasileira de Epidemiologia, 15, 804-806. http://dx.doi.org/10.1590/S1415-790X2012000400012

[9] Santos, M.G., et al. (2008) Fatores de risco no desenvolvimento da aterosclerose na infância e adolescência. Arquivos Brasileiros de Cardiologia, 90, 301-308.

[10] Corso, A.C.T., et al. (2012) Fatores comportamentais associados ao sobrepeso e à obesidade em escolares do Estado de Santa Catarina. Revista Brasileira de Estudos de População, 29, 117-131. http://dx.doi.org/10.1590/S0102-30982012000100008

[11] Silva, V.P. and Zurita, R.C.M. (2012) Prevalência dos Fatores de risco da Obesidade Infantil nos Centros Municipais de Educação Infantil do Município de Maringá-PR 2010. Saúde e Pesquisa, 5, 9-25.

[12] Conde, W.L. and Monteiro, C.A. (2006) Body Mass Index Cutoff Points for Evaluation of Nutritional Status in Brazilian Children and Adolescents. The Journal of Pediatrics, 82, 266-272. http://dx.doi.org/10.2223/JPED.1502

[13] Abbes, P.T., Lavrador, M.S.F., et al. (2011) Sedentarismo e variáveis clínico-metabólicas associadas à obesidade em adolescentes. Revista de Nutrição, 24, 538-539. http://dx.doi.org/10.1590/S1415-52732011000400002

[14] Bhandari, R., Xiao, J. and Shankar, A. (2012) Urinary Bisphenol A and Obesity in US Children. American Journal of Epdemiology, 177, 1263-1270. http://dx.doi.org/10.1093/aje/kws391

[15] Nascimento, H., Costa, E., Rocha-Pereira, P., Rego, C., et al. (2012) Cardiovascular Risk Factors in Portuguese Obese Children and Adolescents: Impact of Small Reductions in Body Mass Index Imposed by Lifestyle Modifications. The Open Biochemistry Journal, 6, 43-50. http://dx.doi.org/10.2174/1874091X01206010043

[16] Madeira, I.R., Carvalho, C.N.M., Gazolla, F.M., et al. (2008) Resistance (HOMA-IR) Ponto de corte do índice Homeostatic Model Assessment for Insulin Resistance (HOMA-IR) avaliado pela curva Receiver Operating Characteristic (ROC) na detecção de síndrome metabólica em crianças pré-púberes com excesso de peso. Arquivos Brasileiros de Endocrinologia \& Metabologia, 52, 1466-1473. http://dx.doi.org/10.1590/S0004-27302008000900010

[17] Ramos, A.T., et al. (2011) Perfil lipídico em crianças e adolescentes com excesso de peso. Revista Brasileira de Crescimento e Desenvolvimento Humano, 21, 780-788. http://pepsic.bvsalud.org/scielo.php?script=sci_arttext\&pid=S0104-12822011000300004

[18] Rossetti, M.B., Britto, R.R. and de Carvalho Norton, R. (2009) Prevenção primária de doenças cardiovasculares na obesidade infanto-juvenil: Efeito anti-inflamatório do exercício físico. The Revista Brasileira de Medicina do Esporte, 15, 472-475. http://www.studiovippersonal.com.br/wp-content/uploads/2011/08/obesidade_infanto_juvevil_2009.pdf

[19] Costa, R.F., et al. (2012) Síndrome metabólica em adolescentes obesos: Comparação entre três diferentes critérios diagnósticos. Jornal de Pediatria, 88, 303-309. http://pesquisa.bvsalud.org/portal/resource/pt/lil-649459

[20] Khan, U.I., Rieder, J., Cohen, H.W., Coupey, S.M. and Wildman, R.P. (2010) Effect of Modest Changes in BMI on Cardiovascular Disease Risk Markers in Severely Obese, Minority Adolescents. Obesity Research \& Clinical Practice, 4, 231-237. http://dx.doi.org/10.1016/j.orcp.2010.03.001

[21] Kitsios, K., Papadopoulou, M., Kosta, K., Kadoglou, N., Papagianni, M. and Tsiroukidou, K. (2013) High-Sensitivity C-Reactive Protein Levels and Metabolic Disorders in Obese and Overweight Children and Adolescents. Journal of Clinical Research in Pediatric Endocrinology, 5, 44-49. http://dx.doi.org/10.4274/Jcrpe.789

[22] Cordero, M.J.A., González-Jiménez, E., Ferre, J.Á., et al. (2011) Study of the Serum Levels of Leptin, Ceruloplasmin and Lipoprotein (a) as Indicators of Cardiovascular Risk in a Population of Adolescents in Granada (Spain). Nutricion Hospitalaria, 26, 1130-1133. http://dx.doi.org/10.1590/S0212-16112011000500032

[23] Nappo, A., Iacoviello, L., Fraterman, A., Gonzalez-Gil, E.M., Hadjigeorgiou, C., et al. (2013) High-Sensitivity C-Reactive Protein Is a Predictive Factor of Adiposity in Children: Results of the Identification and Prevention of Dietary- and Lifestyle-Induced Health Effects in Children and Infants (IDEFICS) Study. Journal of the American Heart Association, 2, Article ID: e000101. http://www.ncbi.nlm.nih.gov/pmc/articles/PMC3698769/?tool=pubmed

[24] Kuba, V.M., Leone, C. and Damiani, D. (2013) Is Waist-to-Height Ratio a Useful Indicator of Cardio-Metabolic Risk in 6-10-Year-Old Children? BMC Pediatrics, 13, 91. http://www.ncbi.nlm.nih.gov/pmc/articles/PMC3686671/pdf/1471-2431-13-91.pdf

[25] Cohen, D. and Damasceno, N.R.T. (2013) Lipoproteína de baixa densidade oxidada (LDLox) versus lipoproteína de baixa desidade eletronegativa [LDL(-)] de adolescentes: análise comparativa. [Dissertação de Mestrado] Faculdade de Ciências Farmacêuticas da USP, São Paulo. 
Scientific Research Publishing (SCIRP) is one of the largest Open Access journal publishers. It is currently publishing more than 200 open access, online, peer-reviewed journals covering a wide range of academic disciplines. SCIRP serves the worldwide academic communities and contributes to the progress and application of science with its publication.

Other selected journals from SCIRP are listed as below. Submit your manuscript to us via either submit@scirp.org or Online Submission Portal.
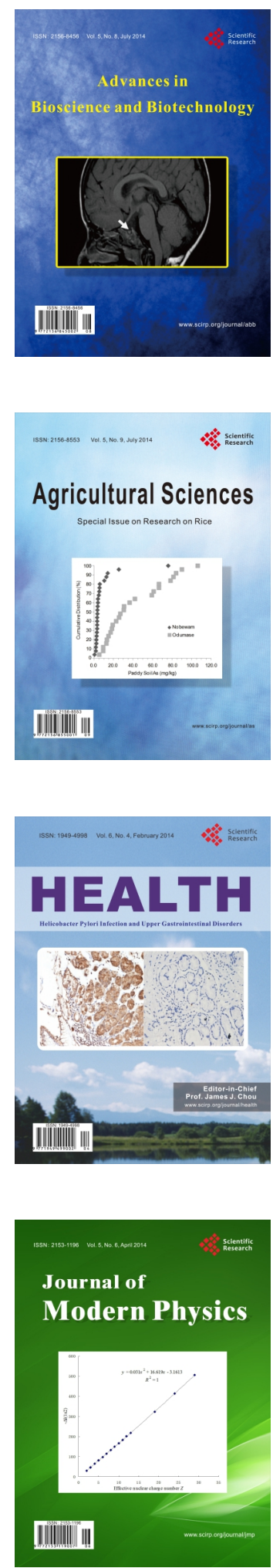
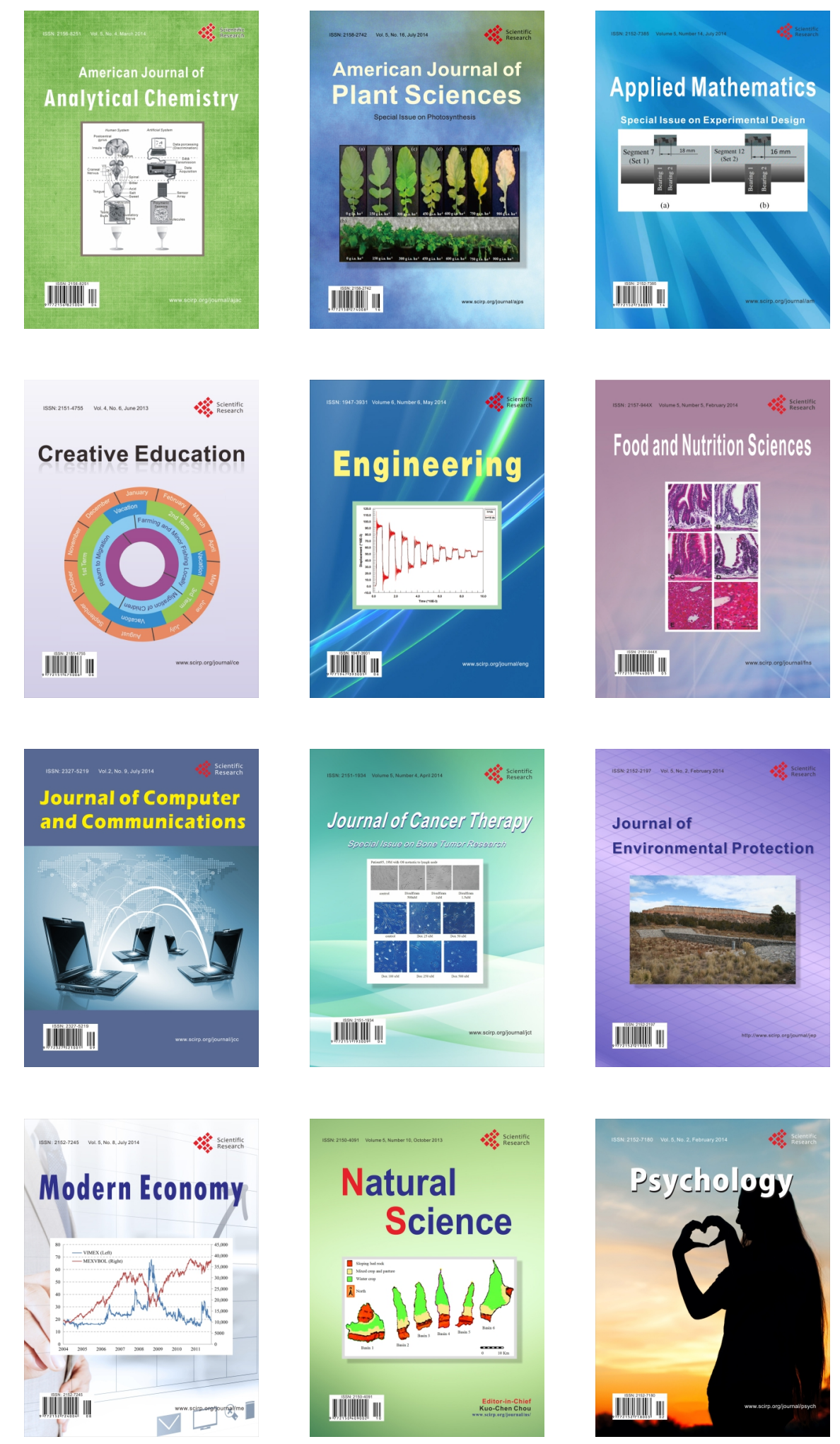